Article

\title{
Understanding the EU's Response to LGBTI Rights Violations: Inter-Institutional Differences and Social Sanctions
}

\author{
Johanne Døhlie Saltnes ${ }^{1, *}$ and Martijn Mos ${ }^{2}$ \\ ${ }^{1}$ ARENA Centre for European Studies, University of Oslo, Norway \\ 2 Institute of Political Science, Leiden University, The Netherlands \\ * Corresponding author (j.d.saltnes@arena.uio.no)
}

Submitted: 31 July 2021 | Accepted: 8 November 2021 | Published: 26 January 2022

\begin{abstract}
This article aims to enrich the literature on EU sanctions in two ways. First, it argues that the absence of material sanctions does not imply a non-response. When faced with human rights violations, policymakers enjoy a third option besides exerting material pressure or refraining from intervening. They may instead employ what constructivist scholars call social sanctions. This option consists of verbally calling out the violators, either publicly, through a naming-and-shaming strategy, or diplomatically via political dialogue and demarches. Social sanctions can be a credible alternative or complement to material sanctions. Second, we argue for the importance of disaggregating the EU as a sender of sanctions. A non-response by executive institutions does not mean that the EU as a whole is standing idly by. Looking at social sanctions alongside material ones more accurately describes the choices policymakers face when designing their response to human rights violations. We demonstrate the value of our arguments by examining the EU's various responses to LGBTI rights violations in Lithuania and Uganda.
\end{abstract}

\section{Keywords}

EU; LGBTI; Lithuania; norm violations; sanctions; sexuality; Uganda

\section{Issue}

This article is part of the issue "Beyond Foreign Policy? EU Sanctions at the Intersection of Development, Trade, and CFSP" edited by Katharina Meissner (University of Vienna) and Clara Portela (University of Valencia).

(C) 2022 by the author(s); licensee Cogitatio (Lisbon, Portugal). This article is licensed under a Creative Commons Attribution 4.0 International License (CC BY).

\section{Introduction}

How do states or international organisations respond to violations of fundamental human rights? This question can be answered dichotomously: They either exert pressure to try to change the wrongdoers' behaviour or refrain from intervening. Sanctions are a popularly used instrument to exert pressure on norm violators. Analyses of external pressure tend to focus exclusively on the imposition of material sanctions. The lack of such sanctions is then automatically seen as a non-response.

However, decisionmakers have a wider array of options than only exerting pressure through material means. For example, when asked if the EU would impose economic sanctions against Russia over its support for the Assad government in Syria, the High Representative for Foreign Affairs and Security Policy of the EU emphasized that "the European Union doesn't only have sanctions in its toolbox, we have many other instruments we can use....We have the instruments for pressure, we also have leverages for good" (Herszenhorn, 2016). These words illustrate that the choice between imposing material sanctions and doing nothing is a false dilemma. When faced with a norm violation, policymakers also enjoy the option of verbally calling out violators, either publicly via the use of a shaming strategy or diplomatically via political dialogue or demarches. Such measures may be either a credible alternative or complement to material sanctions.

What is more, the sanctions literature is preoccupied with the use of material sanctions by executive actors. These typically are national governments. When it comes 
to the sanctions approach of the EU, however, the focus lies with the European Commission whenever human rights violations occur within an EU member state and on the European External Action Service (EEAS) when they take place in a third country. Yet, non-executive actors, such as the European Parliament (EP), also react to human rights violations. Political considerations and distinct competences may mean that their responses differ from those of the executive actor.

Our objective is modest: We wish to introduce greater complexity and accuracy into the analysis of sanctions. A comprehensive understanding of empirical cases requires, we argue, two conceptual moves. First, following the central claim of the thematic issue that the design of sanctions matters, we argue that the sanctions literature has insufficiently explored the possibility of social sanctions as a viable alternative or complement to material sanctions. Any description of how policymakers design their responses to both internal and external norm violations is incomplete without the inclusion of this social side of sanctioning. Second, with specific reference to the $\mathrm{EU}$ as a sender of sanctions, we need to take heed of inter-institutional differences. We propose that scholars study the EP and EU delegations in third states in addition to the current focus on executive actors.

To respond to the weaknesses in the literature, we propose to view social sanctions alongside material ones to obtain a more accurate description of the options policymakers have at their disposal. While the choice to apply material pressure or not is well researched, the options to combine material and social pressure, or "only" make use of social pressure are understudied. Scholars do not often consider these options, but states and international organizations in fact commonly consider and employ them.

To illustrate the added value of our argument, we examine how the EU responded to violations of LGBTI rights in Lithuania and Uganda. The EU's executive actors did not impose material sanctions on either Lithuania or Uganda for encroaching upon the rights of sexual minorities. This absence of material punishment might suggest a non-response. We demonstrate, however, that the EU bodies differed in their reaction. Some in fact sought to shame the violators into mending their ways. We thus illustrate how scholars can arrive at a more nuanced and complete description of their empirical cases by taking social sanctions and inter-institutional differences seriously instead of focusing exclusively on material sanctions.

Two caveats are in order. First, the modesty of our article lies in its concern with the scholarly ability to accurately describe empirical reality. We do not seek to explain why and when policymakers respond in a particular way to human rights violations. The objective is instead to convince readers that they should integrate social sanctions and inter-institutional differences into their analysis of material sanctions. If this message is well received, we invite our colleagues to take this line of research further by explaining variation in how policymakers react to human rights violators. The conclusion discusses our initial ideas on how to transition from description to explanation. Second, our main message should not be mistaken for a normative endorsement of sanctions. Not only is the general effectiveness of sanctions as a policy instrument widely debated (Drezner, 1999; Pape, 1997), but external involvement might be especially problematic for LGBTI citizens whose plight may only worsen as they are denounced as foreign agents and the handmaidens of Western colonialism (Dunne, 2012; Thiel, 2021). We study the potential use of sanctions as an empirical phenomenon and not as a normative ideal.

The article proceeds as follows. The next section uses the dual possibility of material and social sanctions. We subsequently explain why scholars should include the possibility of inter-institutional differences when studying the EU's response to norm violations. We then present our two cases. The conclusion summarizes our main findings, relates them to the other contributions of the thematic issue, and provides some suggestions for future research.

\section{Social Sanctions}

Our starting point is the observation that the literature on sanctions is unduly preoccupied with the actual use of material sanctions. Yet, seeing as this thematic issue understands sanctions as "a temporary abrogation" of normal relations between a sender and a target with the intention to pressure the target "into changing specified policies or modifying behaviour in suggested directions" (Tostensen \& Bull, 2002, p. 374), this preoccupation with the material proves unduly restrictive. We recommend instead that scholars should incorporate negative cases into their analyses and take seriously the possibility of social sanctions. Compared to the literature's focus on positive cases of material sanctions, our conceptualisation better captures the choices that decision-makers face when they are confronted with actions that they perceive as illegal or illegitimate.

The dominant approach in the study of sanctions becomes apparent when looking at the quantitative datasets that underpin much of the literature. For instance, Hufbauer et al. (2007, p. 48) speak of sanctions episodes that commence with the imposition of economic sanctions and end "when the sender or the target country changes its policies in a significant way or when the campaign simply withers away." Their dual focus on positive cases and material sanctions is thus apparent. Subsequent research departed from the work of Hufbauer et al. (2007) in important ways, for example by incorporating the threat of sanctions and by including non-economic sanctions (Biersteker et al., 2018; Hovi et al., 2005; Weber \& Schneider, 2022). They retained, however, the focus on positive cases and material sanctions: The only relevant events are those where the 
outcome of interest, be that the actual or threatened use of sanctions, in fact occurred and where the sanctions were verbal in nature. Whether implicitly or explicitly, these scholars rely on a rationalist logic according to which the sender only imposes material sanctions when the benefits outweigh the costs.

The emphasis on positive cases is also evident in case-study research (Eriksson, 2011; Giumelli, 2013; Portela, 2010). While this literature has provided important insights into the effectiveness of sanctions, senders' motivating factors, and implications and effects on target states and their population, it has paid scant attention to negative cases. When authors do look at instances of non-sanctioning, they have underscored the economic and strategic interests that influence senders' choices (for an overview see Saltnes, 2021). This focus on costbenefit considerations obscures the possibility that sanctions also have a more social dimension.

For the literature to more accurately reflect the decisions that policymakers make when faced with a human rights violation, we suggest that scholars should widen their lenses in two ways. First, they should pay more attention to negative cases where, following Mahoney and Goertz (2004, p. 654), the outcome of interest "has a real possibility of occurring." Recalling Sartori's (1970) call for the systematic investigation of like cases, we hold that it is equally important to investigate those cases where sanctions of some sort were considered but decided against, to avoid a selection bias.

Second, the focus on material sanctions entails the neglect of another type of pressure that constructivist scholars of International Relations have long taken seriously: social sanctions (Friman, 2015; Johnston, 2001). Social sanctions concern "punishments that rely on social or moral leverage, the removal of social status, and targets' embarrassment and concern for social standing to provoke behavioural change" (Erickson, 2020, p. 100). The most prominent type of social sanction is shaming: the public identification by one actor of another actor's norm violations in the hope that this will sufficiently embarrass the target into desisting "such widely condemned actions" (Franklin, 2015, p. 44). Yet, social sanctions may also take other forms, including shunning or even positive reinforcement through backpatting (Johnston, 2001).

Contrary to the rationalist weighing of costs and benefits, an intersubjective logic undergirds social sanctions. Social sanctions require a certain level of "normative consensus about what 'good' behaviour looks like"
(Johnston, 2001, p. 501). If such consensus exists, social sanctions are expected to motivate norm-violating actors to change their behaviour in a way that is consistent with their in-group identity. Social sanctions thus work through peer pressure, social exclusion, or persuasion.

The neglect of social sanctions in the general literature on sanctions is problematic for two reasons. First, it risks confusing the non-imposition of material sanctions with inaction. When an actor refrains from taking economic measure in response to an alleged norm violation, this does not mean that she stands idly by. Social sanctions can be a credible alternative to material sanctions. Second, there is a danger of overstating the importance of material sanctions. When an actor issues both social and material sanctions, most studies only register the latter (e.g., Barber, 1979; Eriksson, 2011; Hovi et al., 2005). Any effect of social pressure is then falsely attributed to material influence. Scholars should therefore take care to keep these interpersonal and coercive dimensions of sanctioning separate. This requires them to incorporate social sanctions into their analyses.

When both negative cases and social sanctions are factored in, the outcome of interest is no longer merely the actual use of material influence. Instead, we see four possible responses to norm violations. Table 1 displays how the range of possible outcomes increases when we analyse social sanctions alongside material ones.

First, an actor may exert combined pressure. This means that she will verbally reprimand another actor for violating international standards while also taking decisive action. Material and social sanctions thus work in conjunction. Most positive cases are in fact cases of combined social and material sanctions. Second, occasionally material sanctions are used in isolation. The sender communicates the punitive measures that they have taken without any intention to shame. For example, following the coup that took place in Mali in 2012, the European Commissioner for Development drily announced that he had "decided to suspend temporarily [sic] European Commission's development operations in the country until the situation clarifies" (European Commission, 2012). Third, under the inverse scenario an actor only exerts social pressure without following through with material sanctions. This, as our cases illustrate, happens quite often. Finally, the ultimate negative case is one in which an actor exerts no pressure, but instead allows a norm violation to go unpunished.

We make a two-part suggestion. First, the sanctions literature should take seriously cases where no material

Table 1. Possible responses to norm violations.

\begin{tabular}{llcr}
\hline & & \multicolumn{2}{c}{ Social response } \\
\cline { 3 - 4 } & & Used & Not used \\
\hline \multirow{2}{*}{ Material response } & Used & Combined material and social sanctions & Material sanctions \\
\cline { 2 - 4 } & Not used & Social sanctions & No sanctions \\
\hline
\end{tabular}


sanctions followed a perceived norm violation. Second, however, this absence of coercive measures should not be mistaken for non-action. Actors may have preferred social over material sanctions.

We demonstrate the value of our propositions in two case studies of how the EU responds to LGBTI rights violations. The EU treats the promotion and protection of LGBTI rights as a core part of its identity (Eigenmann, 2021). This requires it to respond whenever a state encroaches upon the rights of LGBTI people. Since such rights violations may occur not only outside of the EU's borders but also in one of the member states, we examine the use of sanctions at home and abroad (see Hellquist, 2019). Internally, where material pressure is uncommon, we explore the EU institutions' reactions to the Lithuanian Law on Minors. In external relations, where material pressure is frequently applied, we explore EU institutions' choice to apply social pressure to Uganda's Anti-Homosexuality Act. These case studies are illustrative of the broader dimensions that we suggest are missing from the literature on sanctions, namely social sanctions and interinstitutional differences. The method applied is a systematic collection and interpretation of justifications provided by policymakers for their choice of approach (Abulof \& Kornprobst, 2017). We engage with two types of justifications: public justifications found in official documents or made by policymakers in a public setting and justifications by policymakers in an interview setting where the interviewees were asked to provide justifications for the EU's choice of actions. Our sources include official EU and member state documents, semistructured interviews with EU officials and stakeholders, and statements by EU decision-makers in news articles (consult our Supplementary File).

\section{Inter-Institutional Differences}

Our second conceptual move starts from the recognition that the EU does not always speak with a single voice. A comprehensive understanding of EU sanctions requires us to break the EU down into its composite parts: the executive, intergovernmental, and parliamentary bodies. These bodies can be internally divided, for instance when member states within the Council and political groups within the EP do not see eye to eye. The problem of disunity may, however, also arise when individual organs of the EU do manage to reach an agreement. Inter-institutional differences may then come to the fore. These differences matter for our argument because they suggest that the responses of different EU actors to a human rights violation need not align. EU bodies may occupy different cells in Table 1.

Internally, the European Commission functions as the guardian of the treaties. The Commission is empowered to respond to member-state compliance with both EU law and fundamental values. Concerning the former, the Commission monitors compliance and may initiate infringement proceedings. At the same time, because legislative proposals from the Commission will only succeed if they receive support from the Council, strategic considerations discourage the executive body from stepping on member states' toes (Mendrinou, 1996). Börzel (2003) consequently argues that the Commission can choose from multiple "compliance strategies." While sanctioning is one such strategy, less coercive options are also available. Despite its formal powers, the Commission employs a "very cautious strategy in using the penalization potentials" when it suspects that a member state violates EU law (Falkner, 2016, p. 48).

Yet, this compliance apparatus is only relevant when the EU's fundamental values are enshrined in concrete legislation. When this is not the case, the Commission can only put social pressure on a wayward member state. It can, as per Article 7 TEU (Treaty on EU), "determine that there is a clear risk of a serious breach" of those fundamental values that are outlined in Article 2 TEU (Consolidated Version of the Treaty on European Union, 2012). Political considerations have, however, made the Commission hesitant to intervene. The Commission prefers to engage rather than to antagonize noncompliant member states, partly out of a concern that coercive action will only shore up domestic support for the offending government and will erode the Commission's own authority (Closa, 2019). The Commission thus only invokes Article 7 TEU in extreme cases.

Externally, however, the executive branch has a larger foreign policy toolbox to choose from. Material measures include Common Foreign and Security Policy (CFSP) and General System of Preferences sanctions as well as the option to suspend aid. Since 2009, the EEAS, the EU'S diplomatic branch led by the High Representative, is responsible for implementing the CFSP as well ensuring the coordination of the EU's external action. EU delegations now fall under the EEAS and are the prime interlocutor for exerting social pressure towards partner states. In addition to material sanctions, the EEAS's foreign policy toolbox includes quiet diplomacy, public criticism, formalised statement, and dialogues (Fraczek et al., 2015). Thus, the EEAS can exert material and social pressure on partner states.

The EP has a long history of styling itself as a champion of human rights (Gfeller, 2014). This history covers the EU's internal as well as external relations. Much to its own chagrin, however, the EP finds itself rather powerless. It cannot impose punitive measures on either member states or third countries. Instead, the Parliament is forced to rely on a series of soft instruments (Feliu \& Serra, 2015, p. 26). Most prominent among these is the adoption of condemnatory reports and resolutions. Other noncoercive tools include organizing hearings, asking parliamentary questions, and participating in relevant intergroups. Internally, the Parliament shares with the Commission and the Council the right to determine that a member state is at risk of breaching fundamental values. It must furthermore consent to an assessment by 
the Council that such a breach has in fact taken place. This, however, exhausts its formal role. The combination of active involvement in human rights and a lack of coercive instruments predisposes the Parliament to the exertion of social sanctions.

Finally, the Council represents the member states. This intergovernmental nature affects its willingness to respond to internal human rights violations. Only the Council can impose sanctions in response to a breach of fundamental values by another member state. Article 7 TEU specifies that a qualified majority within the Council "may decide to suspend certain of the rights deriving from the application of the Treaties to the Member State in question," including voting rights (Consolidated Version of the Treaty on European Union, 2012). This option has never been used. Indeed, there is a real reluctance within the Council to hold individual member states to account (for an analysis, see Closa, 2021). Although individual countries do occasionally speak out against developments elsewhere in the EU and may even bring matters before the European Court of Justice, these occasions are rare.

In external relations, on the other hand, the Council has been more active. Through dispute-settlement mechanisms, it can employ both social and material sanctions. For instance, the EU's agreements with its 79 partner countries in Africa, Caribbean, and the Pacific, outlines a consultation procedure that combines political dialogue with a carrot-and-stick approach. The Council has activated such consultations 24 times since the dispute-settlement procedure was first introduced in 1998 (Saltnes, 2021, p. 114).

There are thus good reasons to expect that the different EU actors will occupy different cells within our table. In the following two sections we explore whether this expectation is met in our cases.

\section{The EU's Response to Internal Violations of LGBTI Rights: The Lithuanian Law on Minors}

How does the EU act when a member state violates the fundamental rights of LGBTI people? To answer this question, we look at a specific case that did not result in material sanctions: revisions to the Law on the Protection of Minors Against the Detrimental Effects of Public Information (hereafter: Law on Minors) in Lithuania. The original law aimed to protect people under the age of 18 against public information that may detrimentally affect their mental health or well-being (Republic of Lithuania, 2002). The list of types of harmful information included pornography, the promotion of suicide, and substance abuse. In 2007, however, a working group of the Seimas, the Lithuanian Parliament, recommended adding the promotion of homosexual relations to the law (Republic of Lithuania, 2008). In the end, lawmakers classified information that "promotes sexual relations" of any kind and that "expresses contempt for family values and encourages the concept of entry into marriage and creation of a family other than stipulated in the Constitution...and the Civil Code" as harmful. Because both documents define marriage as the union of a man and a woman, the intent behind the amendment is evident: to prevent minors from hearing and learning about same-sex relationships.

Ultimately, the EU did not impose material sanctions on Lithuania for its revision of the Law on Minors. This might suggest that the EU stood idly by. We suggest, however, that this seemingly straightforward assessment proves reductive once we factor in both social pressure and inter-institutional differences.

\subsection{European Parliament}

The EP put pressure on the Seimas to retract the proposed revision of the Law on Minors. First, through the adoption of two resolutions condemning the developments in Vilnius, the EP tried to shame Lithuanian lawmakers into retracting their initiative (EP, 2009a, 2011). The first resolution came shortly before the new Law on Minors was set to enter into effect. The second condemnation came in 2011, as the Seimas was contemplating changes to the Code of Administrative Offences. These changes would effectively reinforce the Law on Minors by introducing administrative and criminal sanctions.

On both occasions, the EP questioned the compatibility of the Lithuanian developments with EU law, EU principles and international human rights law more generally. It also reminded the Lithuanian authorities to take their obligations as a member state seriously. The second resolution pointed out that the EU was founded on the "respect for human rights, including the rights of all minorities," and that "the EU Institutions and Member States have a duty to ensure that human rights are respected, protected and promoted in the European Union" (EP, 2011). MEPs thus used these resolutions to reproach Lithuania for violating LGBTI rights.

Yet, the response from Vilnius exposed the EP's limited influence. The Seimas responded indignantly to the naming-and-shaming attempt with a resolution of its own. It denounced the EP's interference as illegitimate and illegal (Republic of Lithuania, 2009). With social sanctions proving ineffective, MEPs could only hope to effect change by convincing the Commission, as guardian of the Treaties, to intervene.

Parliamentary pressure on the Commission initially took the form of parliamentary questions and open letters. For instance, MEP Sophie In 't Veld asked if the Commission agreed that the proposed revisions to the Law on Minors would run counter to "the basic European fundamental rights enshrined in the Treaties...and in the European Convention on Human Rights" (EP, 2009b). The Lithuanian initiative would specifically run afoul of provisions concerning discrimination, freedom of information, and freedom of expression. In an open letter, In 't Veld (2009) accused the Commission of being "shamefully absent and passive in cases of blatant homophobia and discrimination." 
A similar assessment, albeit worded less polemically, was evident in a letter co-signed by the Executive Director of ILGA-Europe, an umbrella organization that promotes the interests of LGBTI people at the European level, and the President of the EP's Intergroup on LGBTI Rights. It called upon the Commission "to take all necessary measures" to ensure Lithuanian compliance with EU legislation (De Meirleir \& Cashman, 2009).

In short, absent the competence to impose material sanctions, the EP resorted to social sanctions. When two resolutions proved unable to shame the Seimas into abandoning their attack on LGBTI rights, MEPs' only option was to put pressure on the European Commission to step in.

\subsection{European Commission}

The European Commission rejected MEPs' calls for material pressure. It repeatedly indicated that it was only equipped to police compliance with EU law, not with the Union's fundamental rights. That is to say, the Commission is only willing to become involved when fundamental rights have been anchored in concrete directives and regulations.

Illustrative of the Commission's stance is the following response by Commissioner Špidla, to MEP In 't Veld:

The Commission strongly condemns all forms of homophobia, which represents an attack on human dignity.... The Commission will closely monitor legislative developments in Lithuania and will ensure that Directive 2000/78/EC is enforced in all Member States. To that end it will use all means within its powers, where necessary including infringement procedures, to the extent the draft law to which the Honourable Member refers falls within the scope of this directive..... In areas not falling within European Community competence, Lithuanian authorities, including courts, are in charge of ensuring the full respect of fundamental rights in Lithuania. (EP, 2009b)

Two points are worth noting. First, the reply underscores the Commission's commitment to the Union's core values regarding LGBTI rights, including human dignity and non-discrimination. When the EP debated its first resolution condemning Lithuania, Jacques Barrot, the Commissioner for Justice, Freedom and Security, therefore noted that the Commission had communicated its misgivings to the Lithuanian authorities (EP, 2009a).

Second, however, this commitment only goes so far. The Commission is prepared to enforce these values only when a concrete piece of EU legislation is at stake. Špidla specifically mentions Directive 2000/78/EC. This Employment Equality Directive prohibits discrimination based on, inter alia, sexual orientation in the realm of employment. This directive's connection to the Law on Minors is tangential at best. Špidla's response should therefore be read as an admission of defeat: Because the Commissioner is unable to relate the situation in Lithuania to relevant EU law, he believes that he cannot act. The Commission thus has a very narrow perception of its competence concerning fundamental rights; when no directive is at stake, it is up to member-state authorities to ensure "the full respect of fundamental rights" (EP, 2009a).

Thus, no action followed when the Seimas finally approved the Law on Minors. Yet, LGBTI activists made a last-ditch effort to spur the Commission on. The Lithuanian Gay League (LGL), Lithuania's main organization for LGBTI rights, and ILGA-Europe submitted a formal complaint to the Commission. They argued that Lithuania violated the Audiovisual Media Services Directive, which specifies that the protection of minors ought "must be balanced with freedom of expression," and several articles in the EU Charter of Fundamental Rights (Kuktoraitè, 2015). LGL recognized the inherent limitations of invoking this specific directive; after all, the law was not designed to protect human rights, but to coordinate national legislation on audiovisual media. Yet, they saw it as "the only entry point" for formally challenging the Law on Minors in Brussels (interview 1).

The Commission soon dashed the activists' hopes. It decided that it was "not planning to pursue infringement proceedings against Lithuania for failure to comply with Union law" because the matter of homosexual propaganda fell outside the directive's scope (European Commission, 2016). The directive only applied to broadcasts originating in another member state, but not "in case a Member State applies restrictive measures in relation to broadcasts originating in that same Member State" (European Commission, 2016). EU law thus remained silent on internal affairs; "in such cases, it is for Member States...to ensure that fundamental rights are effectively respected and protected" (European Commission, 2016). Lithuanian activists were forced to turn to Lithuanian authorities, even though they thought these authorities had violated their rights to begin with. After careful consideration, the Commission thus decided that it lacked the necessary competences for putting material and social pressure on the Lithuanian authorities.

\subsection{The Council of the EU}

Meanwhile, the Council was nowhere to be seen. It did not issue a collective statement on the Law on Minors. Some member states, including the Netherlands and Sweden, did use bilateral channels to convey their concerns over the Law on Minors. Yet, neither these countries nor the Council as a whole cared to play up the issue. For instance, when asked by a Member of Parliament if he would be willing to raise the issue with other European Ministers of Foreign Affairs, the Dutch Minister simply vowed to communicate "the Dutch position on the rights of homosexual, bisexual and transgender 
people" to his Lithuanian colleague (Second Chamber, 2009). Not even the most progressive of member states within the Council ever considered harsh condemnations, let alone sanctions, in response to the erosion of LGBTI rights in Lithuania. Instead, they deferred to the Commission. As Cecilia Malmström, Sweden's Minister of EU Affairs, explained, "the Council does not have a formal role here"; the task of judging "whether a Member State is meeting its obligations under the treaties" falls to the Commission instead (EP, 2009a). The Council, in short, issued neither material nor social sanctions.

In sum, this case study demonstrates that incorporating social sanctions and inter-institutional differences promises to enrich analyses of the EU's response to human rights violations. It is true that the EU failed to impose material sanctions. This assessment, however, obscures the EP's persistent attempts to shame Lithuania into abandoning the Law on Minors. It also leaves unexplored the very different responses of the Council and the Commission: While the former ignored the issue altogether, the latter wished to protect LGBTI rights, but saw itself as hamstrung by its limited legal competences.

\section{The EU's Response to External Violations of LGBTI Rights: The Ugandan Anti-Homosexuality Act}

Social sanctions and inter-institutional differences also matter in the EU's response to human rights violations in third countries. To illustrate this, we tap into the highly controversial anti-LGBTI law that Ugandan lawmakers passed in 2014. The 2014 Anti-Homosexuality Act was first proposed in 2009 by the Ugandan Parliament. Western media referred to it as the "kill-the-gays bill" because it proposed to make same-sex sexual relations a crime punishable by death. Lawmakers ultimately replaced the death penalty with life imprisonment. Although President Museveni signed this reformed proposal into law, the Ugandan Constitutional Court declared it void five months after it was enacted (Jjuuko \& Mutesi, 2018). The EU did not respond by imposing material sanctions. This does not, however, mean that it was neither concerned nor involved with the anti-homosexuality law.

\subsection{The Council of the EU}

The Anti-Homosexuality Act was met by material pressure by many of Uganda's development partners. Several partner states imposed economic sanctions either when the law was first proposed (UK and Sweden) or when the law was passed in 2014 (US, Netherlands, Denmark, and Norway; Saltnes, 2021). Measures by individual member states notwithstanding, the EU Council refrained from placing material pressure on Uganda. Article 96 of the Cotonou agreement allows the Council to act immediately in response to "cases of particularly serious and flagrant violations of human rights" without first attempting to resolve matters through political dialogue
(Partnership Agreement, 2000). The Council did not avail itself of this option to impose material sanctions.

\subsection{The European External Action Service}

Yet, this does not mean that the EU did not exert any pressure on Ugandan authorities. The EEAS, which assists the High Representative in executing EU foreign policy, exerted social sanctions both when the bill was first proposed by the parliament, in the period leading up to and after the bill was passed in February 2014. The EU delegation in Uganda used political dialogue to remind the Ugandan authorities of their obligation under international law to ensure non-discrimination (EEAS, 2014a; Interviews 3,4,5): "The political atmosphere then was quite 'toxic' and our strategy was one that focused primarily on 'silent diplomacy'....The discussions were often held behind closed doors not revealing much to the public" (Interview 2).

The EEAS in Brussels also exerted social public pressure through three public censure statements. High Representative for Foreign Affairs and Security Policy Ashton stated: "I am deeply concerned about the news that Uganda will enact draconian legislation to criminalise homosexuality" (EEAS, 2014b) and "I urge the Ugandan authorities to ensure respect of the principle of non-discrimination, guaranteed in the Ugandan Constitution, and to preserve a climate of tolerance for all minorities in Uganda" (EEAS, 2013). When asked about the possibility to use material pressure, the head of the EU delegation in Kampala denied that this was an option that the EU was considering. In an interview on Ugandan national TV, he stated: "We are not threatening, we have not threatened with aid cuts during the process of legislative adoption of the bill. This is not how Europe operates" (NTV Uganda, 2014).

Despite calls from the EP for a punitive response (see below), EU policymakers were concerned about the possible consequences of material sanctions for LGBTI persons in Uganda: "The biggest fear was that if we speak up, if we put too much pressure this could lead to more discrimination more violence or even more laws, anti-gay laws" (Interview 3). The justification for not imposing material sanctions is linked to the concern for not making the situation more difficult for the affected parties on the ground (see Saltnes, 2021). On the one hand, the EU's approach towards Uganda reveals how violations of LGBTI human rights are shielded from material pressure to a larger extent than other violations of human rights and democratic principles, such as coups, grave instances of corruption, or electoral fraud. On the other hand, there is also a noticeable willingness to exert social sanctions on LGBTI human rights violations. This despite Uganda being one of the EU's most important development partners in the region. Yet, as we shall see, interinstitutional differences came to the fore also in Uganda. The lack of using material sanctions was contested by the EP. 


\subsection{The European Parliament}

The EP advocated for a stronger response. In 2014, in response to the Ugandan law and a similarly repressive initiative in Nigeria, the EP (2014a) adopted a declaration in which it suggested different types of material pressure. First, it raised the option of suspending both countries from the Cotonou Agreement "in view of recent legislation further criminalizing homosexuality." Finally, the EP (2014a) urged the Commission and member states "to review their development cooperation aid strategy with Uganda and Nigeria" not by suspending aid, but by redirecting it to civil society. In the debate preceding the EP resolution, MEP Cornelissen stated:

There can be only one conclusion from our side. Uganda and Nigeria are not living up to their obligations to the Cotonou Agreement, so preparations for their suspension must begin....If not, then we are obviously only moving air here. (EP, 2014b)

MEP Romeva concorded: "We call on the Commission to immediately launch consultations under Article 96 of the Cotonou Agreement." What is emphasised by MEPs as well as the EP resolution is the viewpoint that the proportionality of the human rights violation in Uganda calls for an immediate and tough reaction such as consultations with the view to suspend Uganda from the Cotonou Agreement, and targeted sanctions such as "travel and visa bans, for the key individuals responsible for drafting and adopting these two laws" (EP, 2014a, p. 256). Hence, we observe that the EP acts as a proponent for a more public and punitive approach that includes the use of combined material and social sanctions.

In sum, the Ugandan case reveals that there is a willingness to intervene towards violations of LGBTI human rights. However, the specific nature of this intervention varies among EU institutions. The Council refrained from using their power to initiate the consultation procedure, yet both the EEAS and the EP exerted social pressure. The EP also called upon the Council to initiate consultations and to adopt visa and travel bans. While there is a lack of material pressure by EU institutions in Uganda, it must not be mistaken as a negative case. Although the Council did not activate Article 96, this does not mean that the EU as a whole "did nothing." EU institutions exerted social pressure on Ugandan authorities. The Ugandan case illustrates that social pressure considered a credible alternative to material pressure and is actively used by EU institutions.

Yet, pressure from Western actors, both material and social, might prove insufficient altogether. What nullified the Ugandan 2014 law was not pressure from the outside, but a coalition of civil society organisations in Uganda's efforts to challenge the law before Uganda's Constitutional Court, which in August 2014 declared it nullified due to its inconsistency with the Ugandan Constitution (Jjuuko \& Mutesi, 2018). A new law, the
Sexual Offences Bill was tabled in 2019 and passed by the Ugandan Parliament on 4 May 2021, something which again brings to the fore a debate about what type of pressure international actors can exert on countries that violate human rights (EP, 2019).

\section{Conclusion}

In this article, we have proposed two correctives to conventional studies of EU sanctions. First, when faced with a human rights violation, whether it occurs internally or externally, the EU does not face a binary choice between material sanctions and inaction. It may also consider social sanctions-either as public naming and shaming or as diplomatic pressure through political dialogueas an alternative or complement to material pressure. Second, the EU is not a single actor that responds to human rights violations. Instead, there may be important differences between how EU institutions react. The Council, Commission, Parliament and EEAS can, and as our case studies demonstrate, often do respond differently. Our main claim is thus that the existing literature has downplayed sanctions of a non-material nature and focused unduly on the response of the EU's executive actors. The case studies demonstrated the merits of our approach: We showed how the absence of material sanctions in response to LGBTI rights violations in Lithuania and Uganda should not be mistaken for inaction on the part of all EU bodies.

We see our conceptual message that sanctions scholars should take social sanctions and inter-institutional differences seriously as a starting point for future research. It raises the question of when and why policymakers respond to human rights violations in a specific manner. Why do different EU bodies react differently to the same case? The Lithuanian and Ugandan examples demonstrated such variation.

Yet, EU actors need not be consistent in their approach to rights violations. The Commission's reticence vis-à-vis Lithuania, for instance, stands in stark contrast to its more recent response to similar developments elsewhere. In July 2021, the Commission announced its decision to initiate infringement proceedings against Hungary for violating the fundamental rights of LGBTI people by passing a bill that prohibited the distribution to minors of content promoting or portraying the "divergence from self-identity corresponding to sex at birth, sex change or homosexuality" (European Commission, 2021). This law closely resembles the Lithuanian Law on Minors, yet it elicited a starkly different response. The Commission also threatened to withhold funding from Polish regions and municipalities that created "LGBT-ideology free zones" and sent a letter of formal notice to the Polish government for failing to cooperate on the matter. Such variation can also be observed externally. After an anti-LGBTI crackdown in Tanzania in 2018, the Council of the EU (Mogherini, 2018) recalled its ambassador and conducted "a comprehensive review 
of its policies" towards the country. Although Tanzania was not suspended from the Cotonou Agreement, it received a much more forceful response from Brussels than Uganda had. What explains these differences in the EU's approach to rights violations?

Our case studies suggest some factors that might influence how policymakers respond to a human rights violation. Most obviously, not all EU bodies are equally able to impose material sanctions. Limited powers predispose the EP to naming-and-shaming practices. Legal competence is, however, a necessary but insufficient condition for the use of material sanctions. It is therefore paramount to bring in additional variables. Political will is one such factor. The Commission, for example, dismissed the Audiovisual Media Services Directive as inapplicable with respect to the Lithuanian law, but largely staked its case against Hungary on this legislation. Policymakers might also be motivated by the perceived appropriateness of sanctions. It is possible that EU actors avoid imposing material sanctions on African states because they do not want to be accused of neo-colonial practices (Thiel, 2021) or because they are concerned about material sanctions having negative consequences for affected persons (Saltnes, 2021). Similarly, the perceived effectiveness of sanctions may affect the response to LGBTI rights violations. The stipulation that member states may not use the European Regional Development Fund and the Cohesion Fund to "support actions that contribute to any form of segregation or exclusion" made the threat of withdrawing funding to Polish municipalities and voivodeships highly credible, which likely increased the Commission's willingness to intervene (Regulation (EU) 2021/1058 of the European Parliament and of the Council of 24 June 2021, 2021). These are some of the factors that may help to turn our conceptual contribution into an explanatory framework for how policymakers respond to rights violations.

\section{Acknowledgments}

This work was supported as part of the LEGOF project at ARENA, a research project financed by the Research Council of Norway (grant agreement no. 288707). The authors thank Clara Portela, Katharina Meissner, the participants of the 2021 ECPR Joint Sessions panel "Designing Sanctions: The European Union in Regional and International Affairs," and the three anonymous reviewers for their helpful comments.

\section{Conflict of Interests}

The authors declare no conflict of interests.

\section{Supplementary Material}

Supplementary material for this article is available online in the format provided by the authors (unedited).

\section{References}

Abulof, U., \& Kornprobst, M. (2017). Introduction: The politics of public justification. Contemporary Politics, 23(1), 1-18.

Barber, J. (1979). Economic sanctions as policy instrument. International Affairs, 55(3), 367-384.

Biersteker, T. J., Eckert, S. E., Tourinho, M., \& Hudáková, Z. (2018). UN targeted sanctions datasets (1991-2013). Journal of Peace Research, 55(3), 404-412.

Börzel, T. A. (2003). Guarding the treaty: The compliance strategies of the European Commission. In T. A. Börzel \& R. A. Cichowski (Eds.), The state of the European Union: Law, politics and society (Vol. 6, pp. 197-220). Oxford University Press.

Closa, C. (2019). The politics of guarding the treaties: Commission scrutiny of rule of law compliance. Journal of European Public Policy, 26(5), 696-716.

Closa, C. (2021). Institutional logics and the EU's limited sanctioning capacity under Article 7 TEU. International Political Science Review, 42(4), 501-515.

Consolidated Version of the Treaty on European Union, 2012. http://data.europa.eu/eli/treaty/teu_2012/oj

De Meirleir, D., \& Cashman, M. (2009). Letter to Commissioner Spidla. Lithuanian Gay League. http://www.lgl. It/en/?p=1189

Drezner, D. W. (1999). The sanctions paradox: Economic statecraft and international relations. Cambridge University Press.

Dunne, P. (2012). LGBTI rights and the wrong way to give aid. Kennedy School Review, 12, 66-70.

Eigenmann, L. (2021). "This is a Union of values": The rise of the LGBTI rights norm as part of the EU's identity construction. Social Politics. Advance online publication. https://doi.org/10.1093/sp/jxab028

Erickson, J. L. (2020). Punishing the violators? Arms embargoes and economic sanctions as tools of norm enforcement. Review of International Studies, 46(1), 96-120.

Eriksson, M. (2011). Targeting peace. Understanding UN and EU targeted sanctions. Routledge.

European Commission. (2012). EU suspends its development aid to Mali. https://ec.europa.eu/commission/ presscorner/detail/en/MEMO_12_214

European Commission. (2016, November 7). Your complaint against Lithuania. Unpublished document.

European Commission. (2021, July 15). EU founding values: Commission starts legal action against Hungary and Poland for violations of fundamental rights of LGBTIQ people [Press release]. https://ec.europa.eu/ commission/presscorner/detail/en/ip_21_3668

European External Action Service. (2013). Statement by EU High Representative Catherine Ashton on the adoption of the Anti-Homosexuality Bill in Uganda. http://www.eeas.europa.eu/archives/ashton/ media/statements/docs/2013/131220_05_en.pdf

European External Action Service. (2014a). EU annual report on human rights and democracy in the 
world 2014. https://eeas.europa.eu/sites/default/ files/2014-human-rights-annual_report_en.pdf

European External Action Service. (2014b). Statement by EU High Representative Catherine Ashton on anti-homosexuality legislation in Uganda. http://www.eeas.europa.eu/archives/ashton/ media/statements/docs/2014/140218_02_en.pdf

European Parliament. (2009a). Situation in Lithuania following the adoption of the law on protection of minors. https://www.europarl.europa.eu/doceo/ document/TA-7-2009-0019_EN.html

European Parliament. (2009b). LGBT situation in Lithuania. https://www.europarl.europa.eu/sides/ getDoc.do?pubRef=-//EP//TEXT+WQ+E-20090060+0+DOC $+\mathrm{XML}+\mathrm{V} 0 / / \mathrm{EN} \&$ language $=\mathrm{EN}$

European Parliament. (2011). Violation of freedom of expression and discrimination on the basis of sexual orientation in Lithuania. https://www.europarl. europa.eu/doceo/document/TA-7-2011-0019_EN. html?redirect

European Parliament. (2014a). Consultations to suspend Uganda and Nigeria from the Cotonou Agreement in view of recent legislation further criminalising homosexuality. https://eur-lex.europa.eu/legal-content/ EN/TXT/PDF/?uri=CELEX:52014IP0254\&from=EN

European Parliament. (2014b). Launching consultations to suspend Uganda and Nigeria from the Cotonou Agreement in view of recent legis/ation further criminalising homosexuality. https://www.europarl. europa.eu/doceo/document/CRE-7-2014-03-13ITM-019-02_EN.html

European Parliament. (2019, October 15). 70 MEPs condemn Uganda's persecution of the LGBTI+ community. https://gbti-ep.eu/2019/10/15/70-mepscondemn-ugandas-persecution-of-the-Igbticommunity

Falkner, G. (2016). Fines against member states: An effective new tool in EU infringement proceedings? Comparative European Politics, 14(1), 36-52.

Feliu, L., \& Serra, F. (2015). The European Union as a "normative power" and the normative voice of the European Parliament. In S. Stavridis \& D. Irrera (Eds.), The European Parliament and its international relations (pp. 17-34). Routledge.

Fraczek, S., Huszka, B., Hüttner, C., Körtvélyesi, Z., Majtényi, B., \& Romsics, G. (2015). Mapping, analysing and implementing foreign policy instruments in human rights promotion. FP7-FRAME. https://fp7-frame.eu/wp-content/uploads/2016/ 08/11-Deliverable-6.1.pdf

Franklin, J. C. (2015). Human rights naming and shaming: International and domestic processes. In H. R. Friman (Ed.), The politics of leverage in international relations: Name, shame, and sanction (pp. 43-60). Palgrave Macmillan.

Friman, H. R. (2015). Introduction: Unpacking the mobilization of shame. In H. R. Friman (Ed.), The politics of leverage in international relations: Name, shame, and sanction (pp. 1-29). Palgrave Macmillan.

Gfeller, A. É. (2014). Champion of human rights: The European Parliament and the Helsinki Process. Journal of Contemporary History, 49(2), 390-409.

Giumelli, F. (2013). The success of sanctions: Lessons learned from the EU experience. Routledge.

Hellquist, E. (2019). Ostracism and the EU's contradictory approach to sanctions at home and abroad. Contemporary Politics, 25(4), 393-418.

Herszenhorn, D. M. (2016, October 17). Mogherini downplays talk of new Russia sanctions over Syria. Politico. https://www.politico.eu/article/federeicamogherini-proud-eu-not-involved-militarily-insyria-isil-war-foreign-policy

Hovi, J., Huseby, R., \& Spinz, D. (2005). When do (imposed) economic sanctions work? World Politics, 57(4), 479-499.

Hufbauer, G. C., Schott, J. J., Elliott, K. A., \& Oegg, B. (2007). Economic sanctions reconsidered (3rd ed.). Peterson Institute for International Economics.

In 't Veld, S. (2009). Open letter to the attention of José Manuel Barroso, President of the European Commission. Lithuanian Gay League. http://www.Igl.It/en/ $? \mathrm{p}=1180$

Jjuuko, A., \& Mutesi, F. (2018). The multifaceted struggle against the Anti-Homosexuality Act in Uganda. In N. Nicol, A. Jjuuko, R. Lusimbo, N. J. Mule, S. Ursel, A. Wahab, \& P. Waugh (Eds.), LGBT human rights: (Neo)colonialism, neoliberalism, resistance and hope (pp. 269-306). School of Advanced Study University of London.

Johnston, A. I. (2001). Treating international institutions as social environments. International Studies Quarterly, 45(3), 487-515.

Kuktoraitè, E. (2015). European Commission began investigation regarding LGL's appeal under the EU Directive Infringement Process. Lithuanian Gay League. http://www.lgl.lt/en/?p=10361

Mahoney, J., \& Goertz, G. (2004). The possibility principle: Choosing negative cases in comparative research. American Political Science Review, 98(4), 653-668.

Mendrinou, M. (1996). Non-compliance and the European Commission's role in integration. Journal of European Public Policy, 3(1), 1-22.

Mogherini, F. (2018, November 15). Declaration by $H R$ Federica Mogherini on behalf of the EU on EU-Tanzania relations [Press release]. https:// www.consilium.europa.eu/en/press/press-releases/ 2018/11/15/declaration-of-hr-federica-mogherinion-behalf-of-the-eu-on-eu-tanzania-relations

NTV Uganda. (2014, April 2). EU Ambassador dismisses aid cuts to Uganda [Video]. https://www.youtube. com/watch?v=1ZXrtqmbZ1Q

Pape, R. A. (1997). Why economic sanctions do not work. International Security, 22(2), 90-136.

Partnership Agreement between the members of the African, Caribbean and Pacific Group of States of the 
one part, and the European Community and its Member States, of the other part, signed in Cotonou on 23 June 2000. (2000). Official Journal of the European Union, L 317. https://eur-lex.europa.eu/legalcontent/EN/TXT/?uri=celex:22000A1215(01)

Portela, C. (2010). European Union sanctions and foreign policy. When and why do they work? Routledge.

Regulation (EU) 2021/1058 of the European Parliament and the of the Council of 24 June 2021 on the European Regional Development Fund and on the Cohesion Fund. (2021). Official Journal of the European Union, L 231/60. http://data.europa.eu/eli/ $\mathrm{reg} / 2021 / 1058 / \mathrm{oj}$

Republic of Lithuania. (2002). Law on the protection of minors against the detrimental effects of public information. https://e-seimas.Irs.It/portal/legalAct/ en/TAD/TAIS.216702

Republic of Lithuania. (2008). Nepilnamečiy apsaugos nuo neigiamo viešosios informacijos poveikio jstatymo pakeitimo ISTATYMO PROJEKTAS (nauja redakcija) [Draft law amending the Law on the Protection of Minors Against the Detrimental Effects of Public Information (recast)]. https://e-seimas.Irs.It/ portal/legalAct/It/TAP/TAIS.343114

Republic of Lithuania. (2009). Resolution on reference of the Republic of Lithuania to the Court of Justice of the European Communities. https://e-seimas. Irs.It/portal/legalAct/lt/TAD/TAIS.358122?jfwid= $57 \operatorname{lm} 4 v 31 r$

Saltnes, J. D. (2021). The European Union and global development: A right-based approach? Routledge.

Sartori, G. (1970). Concept misformation in comparative politics. American Political Science Review, 64(4), 1033-1053.

Second Chamber. (2009). Antwoord vragen Van der Ham over wetgeving in Litouwen die berichtgeving over homoseksualiteit verbiedt [Response to questions by Van der Ham about legislation in Lithuania that bans reporting on homosexuality]. https://www. tweedekamer.nl/kamerstukken/kamervragen/ detail?id=2009D36214

Thiel, M. (2021). The European Union's international promotion of LGBTI rights: Promises and pitfalls. Routledge.

Tostensen, A., \& Bull, B. (2002). Are smart sanctions feasible? World Politics, 54(3), 373-403.

Weber, P. M., \& Schneider, G. (2022). Post-Cold War sanctioning by the EU, the UN, and the US: Introducing the EUSANCT Dataset. Conflict Management and Peace Science, 39(1), 97-114.

\section{About the Authors}

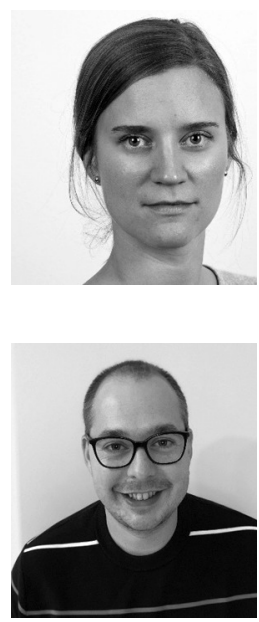

Johanne Døhlie Saltnes (PhD) is a post-doctoral researcher at ARENA Centre for European Studies, University of Oslo. Her main fields of interests include norms in international politics, EU-Africa relations, global justice theory, and human rights sanctions. Her work has appeared in the JCMS: Journal of Common Market Studies, Journal of European Integration, Cooperation and Conflict, Third World Quarterly, and Global Affairs.

Martijn Mos is an assistant professor of international relations at the Institute of Political Science, Leiden University. His research looks at the contestation of international norms and values, with a particular focus on LGBTI rights in the European Union. His work has been published in East European Politics, European Journal of Politics and Gender, JCMS: Journal of Common Market Studies, and European Journal of Contemporary Research. 